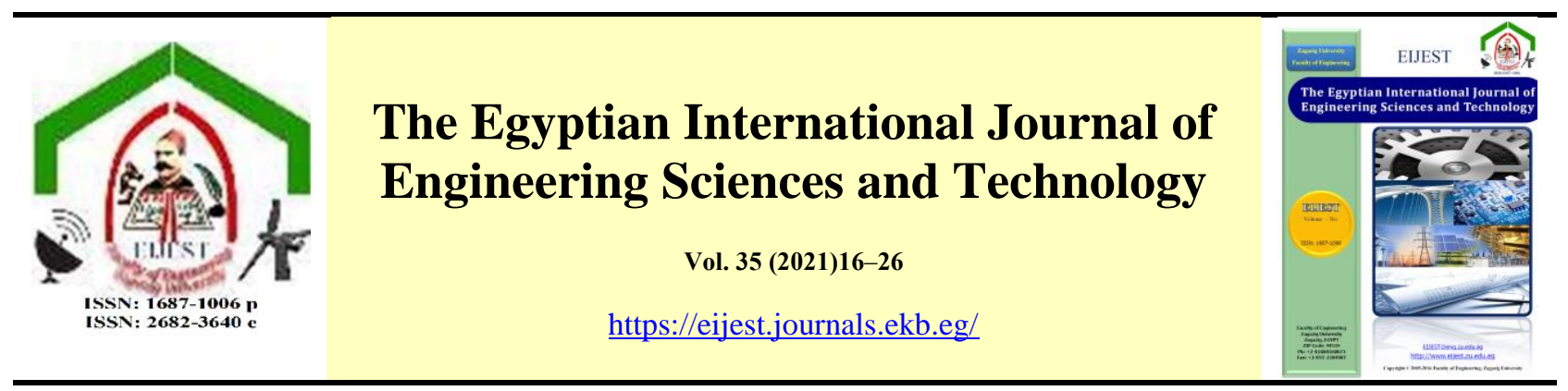

\title{
Integration of microalgae culture as a natural-based solution for wastewater treatment
}

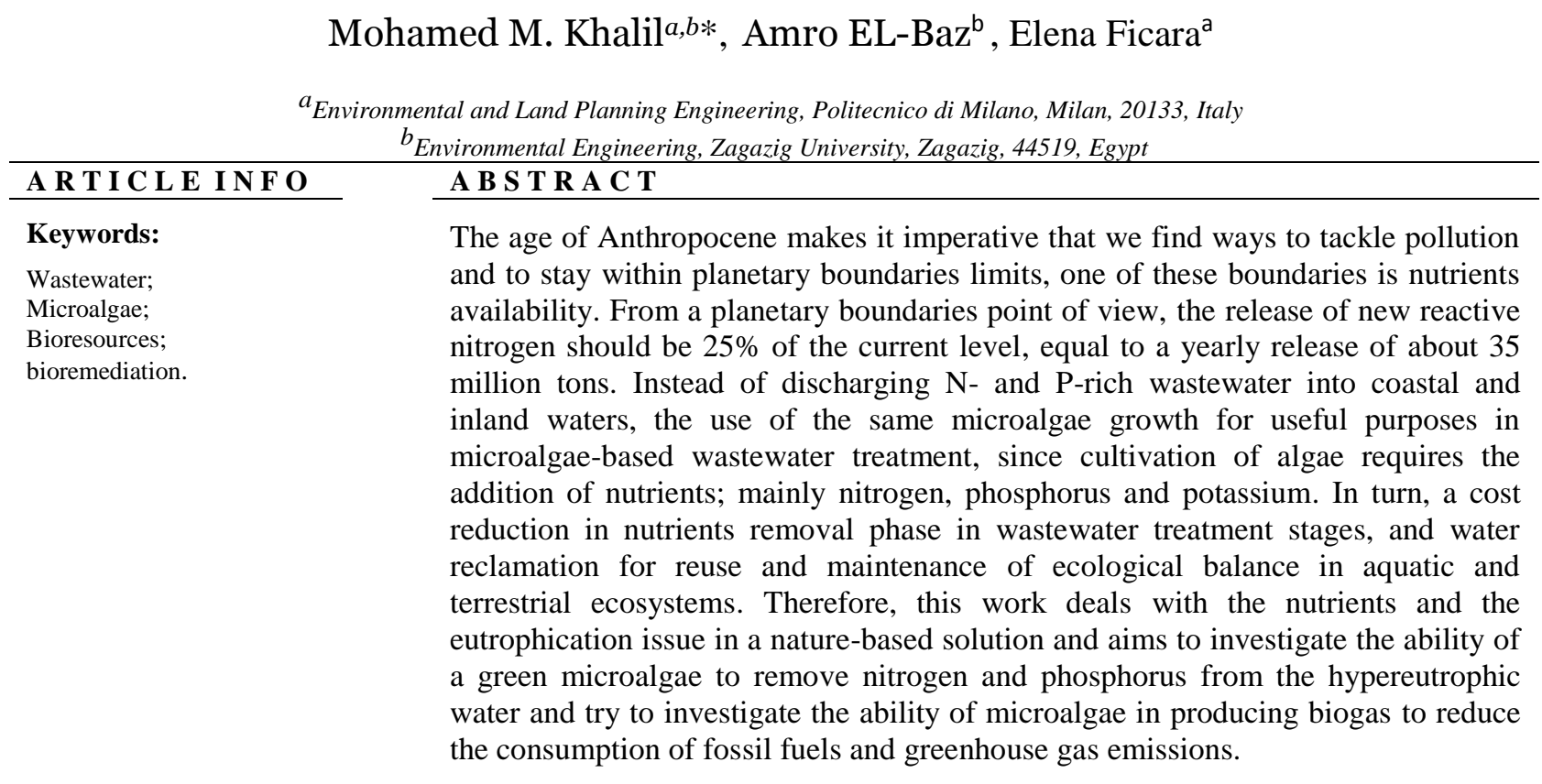

\section{Introduction}

One of the critical boundaries that exceeded the threshold limits is the biogeochemical cycles of nitrogen and phosphorus that have been steeply changed by humans because of many industrial and agricultural processes. Human activities convert about 120 million tons of $\mathrm{N}_{2}$ from the atmosphere into reactive forms each year, mainly to produce fertilizers for food production. Unfortunately, the majority of this new reactive nitrogen seeps into the environment, polluting waterways, and the coastal zone, accumulating in land systems and watersheds. The main reason for this is that in modern agriculture, nutrients are often applied to fields to maximize production. However, farmers often apply more nutrients than are taken up by the plants, the plant takes only its needs and runoff can leach the mineral nitrogen and phosphorus from the detritus to supply the waters, driving ecosystems to natural eutrophication [1]. Eutrophication was recognized in the mid-20th century as a water pollution problem in European and North American lakes and reservoirs, involving three ecological effects of particular concern: reduced species diversity, changes in species composition and dominance, and toxic effects [2]. To curb eutrophication, nutrients control is an essential process and there are many physical and chemical ways to remove nutrients from wastewater, but they are costly and produce high levels of sludge [3] For these reasons, the biological treatment is adapted as many species of microalgae such as Chlorella sp., Scenedesmus sp., and Neochloris sp. proven a high capacity in removing nitrogen and

* Corresponding author. Tel.: +2-012-170-2373.

Email addresses: mohammedmostafa@mail.polimi.it. 
phosphorus from a different source of wastewater [3]. This paper discusses in detail the "reduce" and "reuse" part of bioresources highlighting the high nutrient loads of various wastewaters and the role of microalgae for the bioremediation of water bodies in a closed-loop concept and as a nature-based solution [4]. A possible solution to improve the environmental balance and overcome the cost of algae cultivation and the high cost of electricity generation is to integrate algae cultivation with wastewater treatment plants, where algae can be cultivated in a polluted, nutrient-rich watershed, and the biomass produced can then be directly converted into biogas and refined into biomethane.

\section{Microalgae application in environmental protection}

\subsection{Advantage of microalgae-based wastewater treatment}

The approach of the integrated system in environmental engineering gives us the opportunity to tackle a system in a full closed loop to optimize the useful benefits and minimize the threats posed to human health and the environment. Wastewater is seen both as a pollutant that further degrades ecosystems, but also as one of the solutions to many of the major sustainability and climate change issues we face. Researchers around the world are looking for solutions and developing technologies to recover products from wastewater that are both socially acceptable and economically viable.

One of the highly effective natural-based solutions and techniques is the inclusion of microalgae in the treatment process, which is attracting a lot of attention due to its positive properties for biotechnological systems, such as wastewater treatment, which come with many benefits:

1) The nutrients removal efficiency of microalgae-based is higher in comparison with conventional systems for the high levels of $\mathrm{N}$ and $\mathrm{P}$ present in the wastewater. For example, the polluted water by animals like cattle, swine, and poultry contain more ammonia, although microalgae show higher performance [5].

2) In the tertiary stage, nutrients are removed by conventional means; nitrification: wastewater ammonia $\left(\mathrm{NH}_{3}\right)$ is oxidized to nitrite by autotrophic ammonia-oxidizing bacteria (AOB), and the nitrite is then oxidized to nitrate by nitrite-oxidizing bacteria (NOB) under aerobic conditions then denitrification: Here nitrate $\left(\mathrm{NO}_{3}\right)$ and nitrite $\left(\mathrm{NO}_{2}\right)$ are transformed into nitrogen $\left(\mathrm{N}_{2}\right)$. While involving microalgae, the nutrients removed and accumulate in the biomass. (FCC Aqualia, Spain) reported emissions from the $1^{\text {st }}$ approach (the conventional treatment) $1000 \mathrm{kt}$ for $\mathrm{CO}_{2}, 25 \mathrm{kt}$ for $\mathrm{N}$ and $5 \mathrm{kt}$ for $\mathrm{P}$ if $500 \mathrm{Mm}^{3}$ of wastewater is treated per year. But in the $2^{\text {nd }}$ case for involving microalgae, the same amount of treated wastewater would produce about $500 \mathrm{kt}$ of microalgae biomass annually, with nutrients assimilated in the biomass and not released into the atmosphere [6].

3) Higher energy requirements in case of the conventional activated sludge process due to the aeration process to keep dissolved oxygen within limits for bacterial metabolism. Spain reported 0.5 $\mathrm{kWh} / \mathrm{m}^{3}$ of energy consumption for wastewater treatment (WWT), while in case of microalgae integration, the consumption reduced to $0.2 \mathrm{kWh} / \mathrm{m}^{3}$ wastewater [6].

4) The final cost of microalgae-based wastewater treatment is lower compared to conventional wastewater treatment.

5) Algae based biofuels production is more efficient when integrated into existing WWTPs [7]

6) GHG emissions are lower in case of the microalgae-based wastewater due to lower energy consumption.

7) Many co-products of microalgae-based wastewater as being a sustainable feed for animal and aquaculture feed [8]. Dry biomass residues obtained after the extraction of proteins, lipids or carbohydrates, referred to spent microalgal biomass, which could be sent for energy recovery or other uses [9].

\subsection{Renewable energy}

Our economy and development are built on energy, and all countries accelerated to provide clean energy comes from natural sources or processes that are replenished continuously instead of burning fossil fuels like coal, oil, and gas that end up to carbon pollution causing climate change and environmental issues. One of these clean resources that represent a vital energy source and have received great attention through the past decades, is bioenergy derived from biological sources as being the largest renewable energy. Global bioenergy statistics reported in the main annual publication of World Bioenergy Association (WBA), 2017 that bioenergy accounted for $70 \%$ of the renewable energy consumption. Therefore, global biofuel production rose by 10 billion liters in 2018 to a record 154 billion liters. This is double the 2017 figure and the highest annual 
increase in five years (7\%). Production is forecast to rise $25 \%$ by 2024 [10]. This reflects positively in improving fuel security, mitigating climate change, and supporting rural development. Biofuels can be produced from a huge range of organic materials through a variety of technological production pathways, producing different fuels. There are three different generations characterized by their sources of biomass, feedstock includes cereals, sugars, oil crops, and residues along with the municipal waste. Finally, microalgae which have a large potential in the future.

Microalgae are currently promoted as thirdgeneration biofuels due to many aspects such as their rapid growth rate, role in $\mathrm{CO}_{2}$ bio-fixation, and high lipid production capacity; they also do not compete with food or feed crops and can be produced on nonarable land. Microalgae have broad bioenergy potential as they can be used to produce liquid transportation and heating fuels, such as biodiesel and bioethanol. The algal biomass produced and harvested could be converted into biofuels by different routes, e.g. biogas by anaerobic digestion, biodiesel by transesterification of fats, bioethanol by fermentation of carbohydrates and bio-crude oil by high temperature conversion. Biofuels based on various organic substances make it possible to store energy chemically and also to use it in existing engines and transport infrastructures after blending it to varying degrees with petroleum diesel.

\section{3. $\mathrm{CO}_{2}$ bio-fixation}

Global warming is one of the major concerns for the international community. This issue concerns them because of the escalating concentration of gases, with carbon dioxide $\left(\mathrm{CO}_{2}\right)$ being the main dominator, responsible for up to 60 percent of total greenhouse gases [11]. $\mathrm{CO}_{2}$ concentrations have levelled off at a high level from pre-industrial levels of $280 \mathrm{ppm}$ to about $410 \mathrm{ppm}$ in July $2020^{1}$. It is predicted that its contribution will reach $570 \mathrm{ppm}$ by Twenty-Second century. Reflecting on the world temperature with a possible rise of $2^{\circ} \mathrm{C}$, while the sea level could experience an average rise of $38 \mathrm{~cm}$ [12]. Pushing the world to assign the Kyoto protocol in 1997 to adapt policies for greenhouse gas reduction. Now, there are three main actions to mitigate and remove excess atmospheric $\mathrm{CO}_{2}$ : (1) Chemical/physical fixation techniques like scrubbing, adsorption, cryogenics, and membranes, (2) The storage of $\mathrm{CO}_{2}$ from the atmosphere to the underground or into the ocean, and (3) $\mathrm{CO}_{2}$ bio-

\footnotetext{
${ }^{1}$ https://www.esrl.noaa.gov/gmd/ccgg/trends/global.html
}

fixation through biological mitigation. However, the effective the first two strategies are, they have some disadvantages, as they are not environmentally friendly and require a lot of space and high investment costs. These reasons make the $3^{\text {rd }}$ option of bio-fixation the focus of attention. Trees are responsible for $\mathrm{CO}_{2}$ bio-fixation through the photosynthesis process. But, because of their slow growth, they are able to remove only (3-6\% of $\mathrm{CO}_{2}$ ) in the overall reduction in atmospheric $\mathrm{CO}_{2}$, when compared to microalgae, a study [13] found that to produce $1 \mathrm{t}$ algae biomass, about $1.8 \mathrm{t} \mathrm{CO}_{2}$ is consumed. as carbon is the main element of microalgae (36-65\% of the dry matter) [14].

Therefore, microalgae like trees contribute to keeping $\mathrm{CO}_{2}$ balance by two stages: mass transfer and photosynthesis. The bio-fixation process efficiency depends on the species and operation conditions which can vary in a wide range, so it is necessary to select suitable kind of algae under suitable conditions.

\subsection{Bio-products}

As shown in Table 1, algal biomass is involved in many applications like aquaculture, animal feed, food, pigments, cosmetics, chemicals, energy generation via fermentation, and organic fertilizers [15]. As proteins represent $50-70 \%$ of the microalgae biomass, it is mainly used in human and animals' nutrition. Furthermore, proteins and pigments have their potential for many medical and pharmaceutical purposes. These pigments include carotenoids, chlorophylls, and phycobiliproteins and are the precursors of vitamins in food and feed, dyes, biomaterials, and are used in the cosmetic and pharmaceutical industries. Different valuable pigments are extracted from microalgae, for example, astaxanthin and $\beta$-carotene can be extracted from Haematococcus pluvialis and Dunaliella salina respectively. One of the most important pigments are phycobiliproteins, which are used as natural dyes and in health sector as antioxidant, anti-allergic and anticancer. Moreover, phycocyanin is a natural colour for soft drinks, desserts, ice creams, chewing gum and milk shakes [16]. Astaxanthin has strong anti-aging, sun proofing and anti-inflammatory properties. Fatty acids like DHA and EPA extracted from microalgae are the main sources of nutrients for zooplankton and fishes and are a primary source for nutritional products such as dairy, bakery and eggs quality as high-DHA omega-3 algae can help bring healthier and more productive animals. 
Table 1: bio-products obtained from different algal stains [17]

\begin{tabular}{|c|c|c|c|}
\hline No & Products & Strains & Applications \\
\hline 1 & $\begin{array}{l}\text { Phycocyanin, } \\
\text { protein, vitamin } \\
\mathrm{B}_{12} \text {, biomass }\end{array}$ & $\begin{array}{l}\text { Arthrospira, } \\
\text { Spirulina sp. }\end{array}$ & $\begin{array}{l}\text { Health, } \\
\text { cosmetics, } \\
\text { antioxidant } \\
\text { capsule }\end{array}$ \\
\hline 2 & $\begin{array}{l}\text { Biomass, } \\
\text { carbohydrate }\end{array}$ & Chlorella sp. & $\begin{array}{l}\text { Animal } \\
\text { nutrition, health } \\
\text { drinks, food } \\
\text { supplement, } \\
\text { feed surrogates }\end{array}$ \\
\hline 3 & $\begin{array}{l}\text { Carotenoids, } \beta \text { - } \\
\text { carotene }\end{array}$ & $\begin{array}{l}\text { Dunaliella } \\
\text { salina }\end{array}$ & $\begin{array}{l}\text { Health, food } \\
\text { supplement, } \\
\text { feed }\end{array}$ \\
\hline 4 & $\begin{array}{l}\text { Carotenoids, } \\
\text { astaxanthin }\end{array}$ & $\begin{array}{l}\text { Haematococcu } \\
\text { s pluvialis }\end{array}$ & $\begin{array}{l}\text { Health, } \\
\text { pharmaceuticals } \\
\text {, feed additives }\end{array}$ \\
\hline 5 & Lipids, fatty acids & $\begin{array}{l}\text { Phaedactylum } \\
\text { tricomutum }\end{array}$ & $\begin{array}{l}\text { Nutrition, } \\
\text { biofuel }\end{array}$ \\
\hline 6 & $\begin{array}{l}\text { Biomass, } \\
\text { eicosapentaenoic } \\
\text { acid (EPA) }\end{array}$ & $\begin{array}{l}\text { Nannochlorop } \\
\text { sis oculata, } \\
\text { Nannochlorop } \\
\text { sis sp. }\end{array}$ & $\begin{array}{l}\text { Nutrition, feed } \\
\text { for larvae and } \\
\text { juvenile marine } \\
\text { fish }\end{array}$ \\
\hline 7 & Polysaccharides & $\begin{array}{l}\text { Porphyridium } \\
\text { cruentum }\end{array}$ & $\begin{array}{l}\text { Pharmaceuticals } \\
\text {, cosmetics }\end{array}$ \\
\hline 8 & EPA & $\begin{array}{l}\text { Phaeodactylu } \\
\text { m tricornutum, } \\
\text { Nannochlorop } \\
\text { sis, Nitzchia }\end{array}$ & $\begin{array}{l}\text { Food } \\
\text { supplement, } \\
\text { nutrition }\end{array}$ \\
\hline
\end{tabular}

One more technique that takes advantage of microalgae is the "Partitioned Aquaculture System" (PAS). It is a technique for integrating algae nursery ponds and fish aquaculture to produce a sustainable, low impact, high yielding and more controllable fish production process [18]. Finally, one of the most valuable usages of microalgae which relevant to the topic of this study is to convert them into biofertilizers for agriculture, taking advantage of their nitrogen content and other positive effects as specific substances that are produced by microalgae can exert to plant growth.

\section{Biogas production}

\subsection{Anaerobic digestion-general concept}

One of the main targets of this project is to produce biogas from an organic matter which, in our case, is microalgae biomass. Therefore, an Anaerobic Digestion (AD) process is used to produce biogas, mainly methane (55-75\%) and carbon dioxide (2545\%) through multiple steps as shown in Figure 1 [19]. Anaerobic digestion is widely used because of its advantages over other biofuels production technologies, such as lower operational and capital costs, lower internal energy consumption, higher biomass conversion yield, and feasibility of using wastewater and biomasses grown of wastewaters as substrate for biogas production.

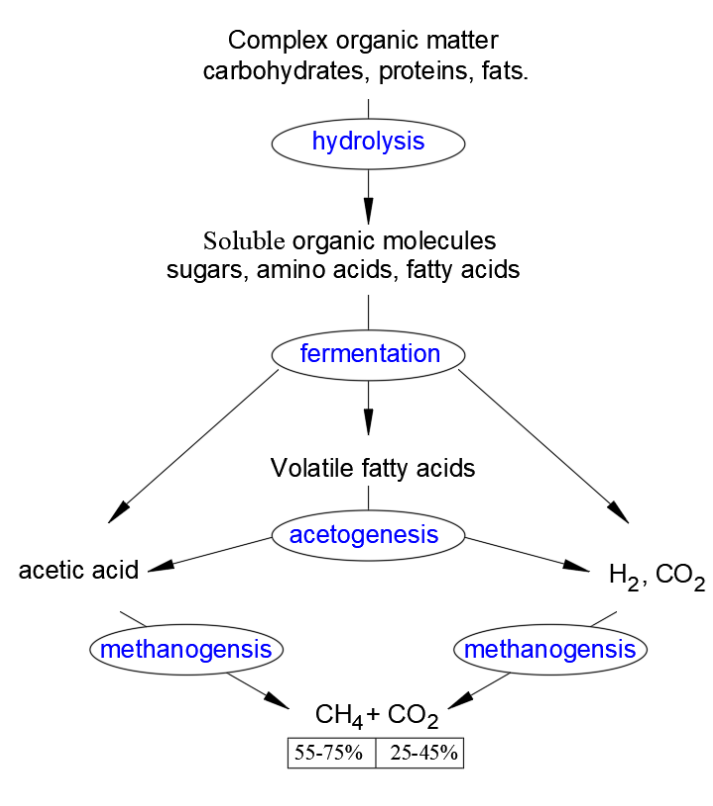

Figure 1. Anaerobic digestion main process starting by dry matters till biogases

A complete $\mathrm{AD}$ plant consists of 4 processes that should be followed. Starting with the hydrolysis step to break down the polymeric components (carbohydrates, proteins and lipids) to monomeric components. Next, the carbohydrates are degraded to glucose and fructose, the proteins are degraded to amino acids, and the lipids are degraded to longchain fatty acids. In the next step of degradation, the components resulting from the last step are broken down into smaller components, such as short-chain volatile fatty acids (VFAs), $\mathrm{CO}_{2}, \mathrm{H}_{2}$, and acetic acid. In the acetogenesis step, these VFAs are also converted to acetic acid and $\mathrm{H}_{2}$. Finally, during methanogenesis, acetic acid is converted to methane by the action of methanogenic bacteria.

\section{- Biogas upgrading}

The final gaseous product that gets out of the digester is biogas. Since biogas is a mixture of methane and $\mathrm{CO}_{2}$ with small quantities of impurities, like $\mathrm{H}_{2} \mathrm{O}$ vapor, $\mathrm{H}_{2} \mathrm{~S}, \mathrm{~N}_{2}, \mathrm{O}_{2}$, siloxanes, and halocarbons. But the most valuable product is methane which contributes to $(55-75 \%)$ and carbon 
dioxide (25-45\%). Although there are many techniques used to treat or purify biogas in physical, chemical and biological ways. A traditional physical/chemical route is chosen, which can purify methane up to $88-98 \%$, with about $99 \%$ removal efficiency of $\mathrm{H}_{2} \mathrm{~S}$, halocarbons and siloxanes [20]. The Pressure Swing Adsorption (PSA) technique is used by compressing the biogas to a pressure between 4-10 bar then fed to a vessel containing a solid porous adsorbent with a high surface area that retain $\mathrm{CO}_{2}$ then can be injected into the HRAPs and the purified $\mathrm{CH}_{4}$ is recovered at the top of the vessel to be used as a fuel. The overall process for reference components can be described as follows (where biomass production is assumed to be negligible)

$$
\begin{aligned}
& \text { Carbohydrates } \\
& \mathrm{C}_{6} \mathrm{H}_{10} \mathrm{O}_{5}+\mathrm{H}_{2} \mathrm{O} \rightarrow 3 \mathrm{CH}_{4}+3 \mathrm{CO}_{2}
\end{aligned}
$$

$$
\begin{aligned}
& \text { Proteins } \\
& \mathrm{C}_{16} \mathrm{H}_{25} \mathrm{O}_{5} \mathrm{~N}_{4}+14.5 \mathrm{H}_{2} \mathrm{O} \rightarrow 8.25 \mathrm{CH}_{4}+3.75 \mathrm{CO}_{2}+ \\
& 4 \mathrm{NH}_{3}
\end{aligned}
$$

\section{Lipids}

$\mathrm{C}_{50} \mathrm{H}_{90} \mathrm{O}_{6}+24.5 \mathrm{H}_{2} \mathrm{O} \rightarrow 34.75 \mathrm{CH}_{4}+12.25 \mathrm{CO}_{2}$

- Comparison between mesophilic \& thermophilic $\mathrm{AD}$.

The mesophilic approach operates in the range of 30-40 ${ }^{\circ} \mathrm{C}$, while in the thermophilic approach the temperature ranges between 50 and $60{ }^{\circ} \mathrm{C}$. The latter is considered more advantageous since it leads to the following advantages: it increases the degradation rate and the efficiency of volatile solids conversion, higher biogas production rate is obtained, higher organic loading rate can be applied, the risk of foaming is lower, and the digested sludge can be dewatered more efficiently. However, major bottlenecks are presented in the thermophilic approach, such as: higher capital and operational costs due to higher heating temperature and additional thermal insulation, higher risks of odor emissions due to the undegraded VFA, and higher sensitivity to temperature variations [19]. [21] explained in their study the poor performance of algae digestion due to the algal cells and its resistance to the bacterial attack, giving a possible solution for enhancing the process by exposing them to thermophilic treatment. As shown in Figure 2, gas production was uniformly greater at $50{ }^{\circ} \mathrm{C}$ than at 35 ${ }^{\circ} \mathrm{C}$.

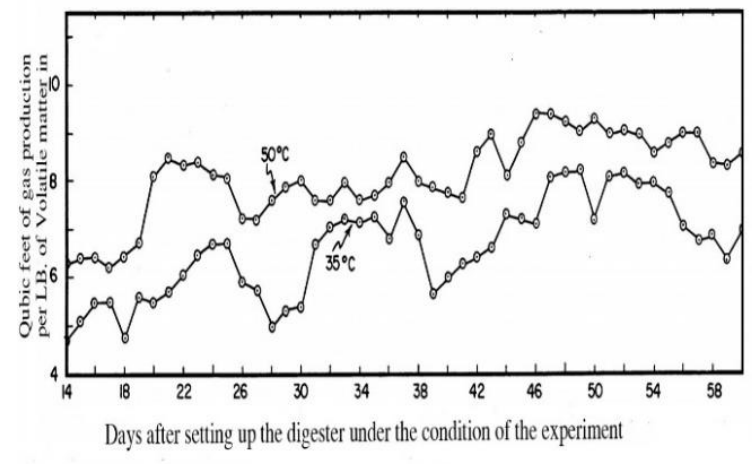

Figure 2: Comparison between mesophilic and thermophilic approaches per pound of volatile matter introduced [21]

\subsection{Biogas plants - general description and design criteria}

The conceptual design of biogas plants is determined by the objective of achieving optimal parameters for the biological process, with certain considerations such as the type and composition of the organic material determining the choice of process, biogas and fertilizer requirements, in addition to the amounts of substrate available, which determine the size of the biogas plant; the total cost for the installation, labor and maintenance. Simple biogas plants can be divided into batch-type which can be charged with batches of organic materials; hence, the digestion process is intermittent, at each biogas rate decrease the plant is cleaned out and refilled. The second category is the continuous feed plants, where there is a continuous flow of biomass, resulting in an almost constant volume of slurry in the digester and a constant supply of biogas.

- General rules in the designing of biogas plants.

1-Organic loading rate (OLR)

It is an important parameter to keep the balance between acidogenesis and methanogenesis; as discussed in Figure 1, acidogenesis provides methanogenesis with VFAs. So, a continuous balance should be maintained between VFA production and consumption rates. Indeed, any accumulation of VFAs in the digester leads to a decrease in $\mathrm{pH}$, which in turn affects the metabolism and growth of methanogenic bacteria. The recommended OLR for microalgae varies depending on the species and the $\mathrm{AD}$ technology. In general, the OLR for optimal anaerobic digestion is $1.6-4.8 \mathrm{~kg} \mathrm{VS} \mathrm{m}^{-3} \mathrm{~d}^{-1}$ [22]. 


\section{2- Carbon/Nitrogen ratio}

The $\mathrm{C} / \mathrm{N}$ ratio must also be balanced, as it plays a virtual role and influences the biogas yield, the optimal range being between 20 and 30 [23]. At a $\mathrm{C} / \mathrm{N}$ lower than 20 , the efficiency decreases and the value of $\mathrm{NH}_{3}$ starts increasing that negatively affects the metabolism and growth of methanogens resulting in VFAs accumulation and eventually decreasing the biogas yield. To optimize the $\mathrm{C} / \mathrm{N}$ ratio, co-digestion can be an effective strategy. As for microalgae, codigestion with other C-rich materials such as pig or cow manure, corn stalk and food and paper wastes can be considered [24].

\section{3- Hydraulic retention time (HRT)}

HRT is the time it takes for the biomass to pass through the reactor and is the time in which the AD conversions take place. The HRT controls the growth of microorganisms, the extent of the metabolic processes, and the formation of the targeted endproducts in the digester. A minimum value exists which allows keeping the methanogenic bacteria and avoiding their washing out. It is true that increasing HRT increasing the generation of biogas, but a long HRT results in larger reactors and in turn, increasing the capital costs. Typically, the optimum HRT for the anaerobic digestion reactor can vary between 30-50 d [19].

\section{4- $\mathrm{pH}$ and alkalinity}

Microbial communities in the anaerobic digestion are very sensitive for $\mathrm{pH}$ levels, in particular methanogens, in a way that their growth drops dramatically below 6.6 [25]. While high $\mathrm{pH}$ levels lead to $\mathrm{NH}_{3}$ generation that has a toxic effect on bacterial activities in the digestor. Many studies measured the optimum $\mathrm{pH}$ to maintain during the process, for instance [26] recommended in his studies that $\mathrm{pH}$ should be between 6.6-7.4.

\subsection{Anaerobic degradability of microalgal biomass}

Methane can be produced from microalgae by anaerobic digestion process as first suggested in 1957 by Golueke using Chlorella sp. and Scenedesmus spinosus. Expected biogas yields range between 0.17 $0.32 \mathrm{~L} \mathrm{CH}_{4} / \mathrm{g}$ VS [21]. In comparison, biogas production compared with fuel crops such as corn stover $0.107-0.241 \mathrm{~L} \mathrm{CH}_{4} / \mathrm{g}$ VS, $0.281 \quad \mathrm{~L} \mathrm{CH}_{4} / \mathrm{g}$ VS for rice straw, $0.245-0.258 \mathrm{~L} \mathrm{CH}_{4} / \mathrm{g}$ VS for wheat straw, $0.125 \mathrm{~L} \mathrm{CH}_{4} / \mathrm{g}$ VS for switchgrass and 0.410.435 for food wastes [19].
- Strategies for improving biogas yield.

The main drawback of digesting microalgae is its hard cell wall, containing hardly biodegradable biopolymers, cellulose, and hemicellulose. To overcome this bottleneck, a pretreatment process is applicable that enhances the digestibility of the microalgal cell wall, which in turn increases methane production [27]. Pretreatment methods are very many and can be classified into four categories: mechanical, thermal, biological, and chemical. [19] referred recently to many results of various pretreatment methods on biogas production from microalgae biomass.

\section{1- Mechanical pretreatment}

Ultrasound, shaking, microwave, and sonication are all methods of mechanical pretreatment to alter the structure of the microalgal biomass by breaking down the cell walls. For instance, [28] mentioned that ultrasonic pretreatment can increase methane yields up to $91 \%$. Microwave can cause cell wall alteration and hydrolysis through induction heating and dielectric polarization, resulting in an increase of biogas production up to $79 \%$; however, it still consumes a lot of energy [27].

2- Thermal hydrolysis

Comparing with all other pretreatment processes, thermal hydrolysis recorded the highest methane production yield that reached up to $123 \%$ [6]. To perform thermal pretreatment of microalgae, heat exposure of $50-270{ }^{\circ} \mathrm{C}$ is required to induce cell modification and solubilization of the biomass, in particular, temperatures of $55-170{ }^{\circ} \mathrm{C}$ have been applied to increase the methane of microalgae [29]. However, there is no fixed value for the optimal temperature as it depends on the microalgae species.

3- Biological pretreatment

Is a promising alternative to energy-consuming pretreatments. It aims to enhance the hydrolysis of the cell walls of microalgae. Hydrolytic enzymes convert cellulose and hemicellulose of the cell wall into easily degradable compounds that are more available to anaerobic bacteria. However, the process requires wise control of key parameters such as enzyme dose, temperature, contact time and $\mathrm{pH}$. There are a variety of enzymes available, the choice depends on the microalgae species. [30] he used the enzyme cellulase to hydrolyze Chlorella pyrenoidosa biomass and noted an increase in lipid extraction efficiency from $32 \%$ to $56 \%$ due to cell wall disruption.

4- Chemical pretreatment

Rarely, chemical pretreatments are applied alone, but generally combined to the thermal one. So, the 
thermo-chemical pretreatment can be carried out by adding acidic (mainly $\mathrm{H}_{2} \mathrm{SO}_{4}$ ) or alkaline (like $\mathrm{NaOH}$ ) reagents with elevating the temperature which leads to the release of the organic compounds. [31] tested the feasibility of adding sulphuric acid to algae biomass (Chlamydomonas reinhardtii and Chlorococcum humicola, respectively) and found increasing in bioethanol production by 2 -fold and 4.5 -fold, respectively. But this option is not desirable for the anaerobic digestion for producing methane.

\section{Technical solutions for growing microalgae in wastewaters}

\subsection{Parameters affecting algal production.}

There are three main classes of factors affecting algal growth: biotic factors, abiotic factors, and operational conditions.

1- Biotic factors

Contamination of the water by the presence of zooplankton grazers and pathogens, such as bacteria, fungi, viruses, and rotifers affect badly the algal growth and can reduce the algal concentration in the short term. It is found that the presence of fungal parasitism and viruses have a damaging influence on the algal cell structure. Furthermore, the presence of cladocerans and rotifers at high concentration $\left(>10^{5} / \mathrm{L}\right)$ has an inverse relationship with the algal concentration and reduces it by $90 \%$ in only two days [28].

\section{2- Abiotic factors}

- $\quad$ Light and temperature

Light and temperature have their deep influence on the algal yield, any increase of them within their optimal interval fosters the algal metabolic activity, while lower temperature or light contributions slow down the microalgal growth. Optimal algal yield is maintained when the temperature varies between 28 and $35{ }^{\circ} \mathrm{C}$ for many algae [28]. Below this range, for example, a sudden temperature drops to $10{ }^{\circ} \mathrm{C}$ for $15 \mathrm{~h}$ ends up to $50 \%$ reduction in chlorophyll-a. On the other hand, higher temperature results in inhibiting the photosynthesis and reducing the growth yield. As for light, many papers [32] described the "Z-scheme" of the light capturing mechanism required for full photosynthesis. The photons are first stored in the form of biochemical compounds and then utilized by the algal cells leading to new biomass. [28] analyzed the photosynthetically active radiation (PAR) and the photosynthetic conversion efficiency to estimate the algal productivity as described as follows:

$p_{\max }=\frac{I_{o^{*}} \eta_{\max }}{E}$

$p_{\max }$ : algal productivity $\left[\mathrm{g} / \mathrm{m}^{2} / \mathrm{d}\right]$

$I_{o}$ : Average solar radiation $\left[\mathrm{MJ} / \mathrm{m}^{2} / \mathrm{d}\right]$

$\eta_{\text {max }}$ : maximum efficiency for algal photosynthetic conversion, only (1.3-2.4\%) of the total solar radiation.

E : Energy value of algal biomass as heat [21 kJ/g].

In most algal cultures grown in HRAPs, a wide range of light density can be found, the photosynthesis increases as light density increases till the maximum point called the saturation point. Light intensity above the saturation point leads to photoinhibition and then, a negative impact and a decrease of yield as seen in Figure 3 [33].

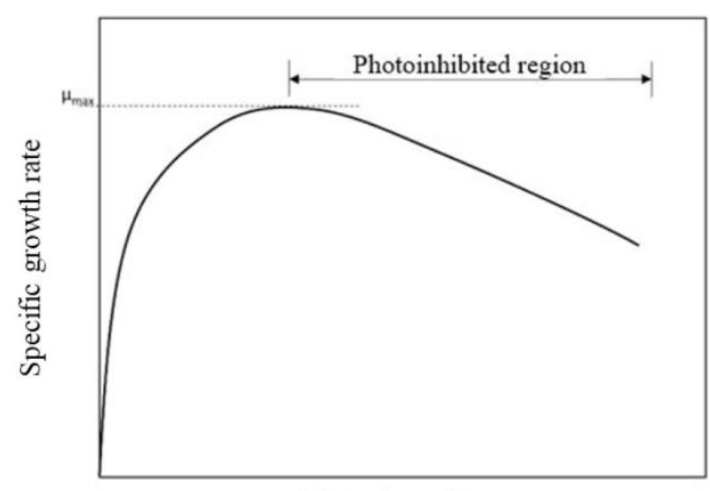

Light intensity

Figure 3: Light intensity effect on microalgae growth rate.

- $\quad \mathrm{pH}$ and $\mathrm{CO}_{2}$ availability

The microalgal growth rate is highly affected by $\mathrm{pH}$. According to the Food and Agriculture Organization (FAO), The $\mathrm{pH}$ range for most cultivated algae species ranging between 7 and 9 , with the optimal range being 8.2-8.7. Below or above that range, the productivity decreases significantly and the cells being unable to thrive [34]. In high-rate algal ponds, this $\mathrm{pH}$ increase can be compensated by sparging $\mathrm{CO}_{2}$ into deeper areas of the pond, and the $\mathrm{pH}$ can then be controlled by adjusting more organic material.

Another factor that is also affecting the $\mathrm{pH}$ value is nitrate assimilation by the algae that tends to raise the $\mathrm{pH}$. But if ammonia is used as a nitrogen source, the opposite happens, the $\mathrm{pH}$ decreases. So usually, a $\mathrm{pH}$ control system dosing $\mathrm{CO}_{2}$ is adopted to keep the mixture meet the specifications, especially because $\mathrm{CO}_{2}$ 
addition showed enhance to the algal productivity via photosynthesis, while the insufficient supply of $\mathrm{CO}_{2}$ inhibits the algal yield as appears in the general equation for photosynthesis.

$\mathrm{H}_{2} \mathrm{O}+\mathrm{CO}_{2}+$ photons $\rightarrow[\mathrm{CH} 2 \mathrm{O}]_{n}+\mathrm{O}_{2}$

- Dissolved oxygen

The presence of dissolved oxygen in high concentration affects adversely on biomass productivity. Several studies [35] [36] highlighted the effect of DO concentration on microalgal growth and found out that the optimum range of DO for a stable microalgal yield varies between 8 g.m $\mathrm{m}^{-3}$ and $25 \mathrm{~g} \cdot \mathrm{m}^{-3}$, and a productivity loss by $30 \%$ happened if DO concentration raised more than 31 g. $\mathrm{m}^{-3}$.

- Nutrients

Algae are mainly autotrophic which means that they can produce organic molecules from inorganic nutrients, and the common elemental composition that represents the algal cell is $\mathrm{C}_{106} \mathrm{H}_{181} \mathrm{O}_{45} \mathrm{~N}_{16} \mathrm{P}$ [37]. After carbon, nitrogen is the second vital element as it forms about $10 \%$ of the microalgal biomass [38]. Nitrogen can be assimilated in different forms, like ammonium $\left(\mathrm{NH}_{4}{ }^{+}\right)$and nitrate $\left(\mathrm{NO}_{3}{ }^{-}\right)$, but the preferred one is ammonium. If ammonium is available, no other nitrogen source will be assimilated.

A second essential nutrient element is Phosphorus which is responsible for energy transfer and nucleic acid synthesis. Adenosine triphosphate (ATP) is resulted from Adenosine diphosphate (ADP) as represented as follows:

$A D P+P_{i} \stackrel{\text { energy }}{\longrightarrow} A T P$

The stoichiometric formula that has been presented before indicates the high ratios between nitrogen and phosphorous (16 molN:molP, i.e. 7.3 g N: g P). However, N:P ratio can vary in a range of $4: 1$ to $40: 1$ based on algal species and nutrients availability [28].

- Operational conditions

Operational conditions like mixing, gas transfer, Hydraulic Retention Time (HRT), and harvesting rate, affect environmental conditions and supposed to be designed in order to provide constant and optimal conditions for light exposure, $\mathrm{CO}_{2}$ availability, and shear rates [39].

\subsection{Wastewater treatment and HRAPs integration}

The three main stages controlling the conventional treatment of wastewater are primary, secondary, and tertiary to remove contaminants from wastewater and convert it to a clean effluent to return it back to the water cycle with minimum harmful effects on the ecosystems. But in 1957 the algal applications have been involved strongly into the system for wastewater treatment. This firstly happened in the U.S. by [40], then has been intensively spread in many countries. This biotreatment was highlighted and got a huge focus due to its high capacity in converting solar energy to biomass, and assimilating nutrients loads from the wastewater. Hence, research, experiments, and efforts are accumulating to develop and figure out the best techniques for integrating the microalgae cultures into wastewater treatment. Indeed, these efforts came out with promising results in removing $\mathrm{BOD}, \mathrm{N}$, and $\mathrm{P}$ in very short periods from different waste categories [41]. It was found that the algal systems can treat human sewage and livestock wastes, organic wastes like agricultural wastes, food processing wastes and piggery effluent, agro-industrial wastes, and industrial wastes [42].

Many microalgal cultivation systems have been developed for wastewater treatment purposes like open ponds, closed photobioreactors, and biofilm reactors [43], as shown Figure 4. Comparing open and closed culture systems, both have their own advantages and disadvantages. For example, productivity in closed photobioreactors is higher than in the open ponds, whereas Sanjay Kumar Gupta in his book "Algal Biofuels: Recent Advances and Future Prospects" stated that productivity of open ponds range between $0.42-0.6 \mathrm{~g} \mathrm{~L}^{-1} \mathrm{~d}^{-1}$ in comparison with productivity range of $0.02-3.22 \mathrm{~g}$ $\mathrm{L}^{-1} \mathrm{~d}^{-1}$ for closed photobioreactors. But closed photobioreactors have many drawbacks due to the high cost and the operation complexity. 


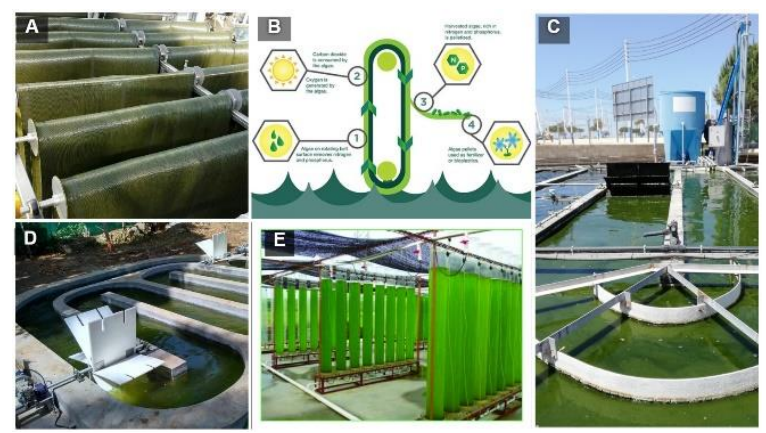

Figure 4: Microalgae Cultivation Systems for Wastewater treatment, Columbus. A, B) Revolving Algal Biofilm (RAB) Wastewater Treatment C) High-Rate Algae Ponds in Aqualia, Spain., D) Race way algal pond, and E) closed photobioreactors, Foshan city, South China.

\subsection{High-rate algal ponds}

One of the most promising techniques in raceway systems is high-rate algal pond (HRAPs) which are paths divided by walls into single or multiple loops that guarantee a gentle and controlled flow, with a depth range between $0.2-0.8 \mathrm{~m}$ with the most common being $\sim 0.3 \mathrm{~m}$ and velocity range between $0.15-0.3 \mathrm{~m} / \mathrm{s}$ provided by a paddlewheel to guarantee effective mixing. A flow of $\mathrm{CO}_{2}$ is added to the mixture directly after the mixing and controlled by $\mathrm{CO}_{2}$ and $\mathrm{pH}$ sensors as appear in Figure 5. It is preferable for the pond bottoms to be lined to prevent leakage and water losses [28].

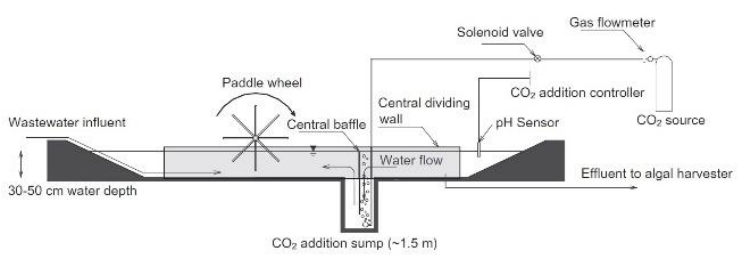

Figure 5: high-rate algal pond schematic [28].

- Algal biomass production and optimization of algal production in HRAPs.

As commented before, microalgae show a production fluctuation due to biotic/abiotic and operational parameters. Increasing the production rate is much sensitive but also more desirable and that could be maintained by developing proper reactor design and process optimization through the following parameters.

1- Light intensity and quality.

As discussed before how light density plays a crucial role in the photosynthesis. One promising technique for enhancing microalgae yield in a highly fluctuating environment is to maintain microalgae consortia that able to establish cooperative interaction through the exchange of metabolites and to adapt to the available growth conditions [39]. One further option to compensate for the natural light shortage is to add Light Emitting Diodes (LEDs) as an artificial light source to improve the delivery of photons [44]. This technology is applied along with the paddlewheel to guarantee the regular distribution of gas and photons.

2- $\mathrm{CO}_{2}$ addition

[28] mentioned a biomass productivity increase by $>30 \%$ in pilot-scale HRAP in New Zealand due to $\mathrm{CO}_{2}$ addition. Furthermore, $\mathrm{CO}_{2}$ addition considers an optimum tool to control $\mathrm{pH}$, and this reflects on the control of ammonia volatilization and phosphate precipitation. These two physico-chemical processes are reduced and generate more production by assimilating more nutrients into the algal biomass. For instance, fixing $\mathrm{pH}$ below 8 by adding $\mathrm{CO}_{2}$, reduces the nitrogen loss by reducing ammonia volatilization to $5-9 \% \mathrm{~N}$ loss compared with $24 \%$ loss in case of normal HRAPs without $\mathrm{CO}_{2}$ addition, this loss reduction maintains an abundance of nitrogen to be assimilated into algal biomass [28]. Many relevant techniques to add $\mathrm{CO}_{2}$, are using available facilities like power plants emissions or the biogas generated from the anaerobic digestion process after upgrading it to Methane and $\mathrm{CO}_{2}$ [45].

\section{3- Control of gazers and parasites}

Much research discussed the applicable solution to control the gazers and parasites. [46] discussed the feasible physical, chemical, and biological techniques to prevent their growth. But three techniques are promising, for their low capital cost and easy handling which are: (A) increasing injection of $\mathrm{CO}_{2}$ to increase its concentration during daytime. $\mathrm{CO}_{2}$ addition was used to get rid of zooplankton in experimental patches. These results discussed the possibility of controlling zooplankton in HRAPs, although maintaining high concentration levels of $\mathrm{CO}_{2}$ is very difficult due to gas exchange. (B) Increasing the ammoniacal-N concentration in the pond leading to promoting ammonia toxicity during the daytime, but more research is required to measure the negative effect on the algal strain. (C) Zooplankton control using fish, fish have been proposed as zooplankton predators in algae production ponds [47]. Species such as silver carp and Nile tilapia have been shown to survive under physicochemical conditions similar to those in HRAPs, because such environments for algal production are shallow, polluted and eutrophic, with 
$\mathrm{pH}$ ranging between $6.5-9.0$ and with a wide range of dissolved oxygen DO [46].

\section{Conclusion}

Wastewater and eutrophic waters are a rich source of nutrients such as phosphorus and nitrogen, so nutrient removal from wastewater in a -natural based solution is urgently needed. In this study, the integration of pollution with bioresource recovery is investigated. Microalgae-based nutrient removal from wastewater serves the dual purpose of bioremediation of eutrophication symptoms plus beneficial production of algal biomass.

\section{Acknowledgements}

I am very grateful to be an ambassador for Zagazig University and to have worked under the supervision of my committee: Dr. Elena Ficara, my supervisor at Polimi; Dr. Amro El-Baz, supervisor at Zagazig University. I express my sincere appreciation for their efforts, kindness and learning opportunities provided by them. Moreover, the visions proposed by them have broadened my horizon and strengthened the research.

\section{References}

[1] W. Ejankowski and T. Lenard, "TROPHIC STATE OF A SHALLOW LAKE WITH REDUCED INFLOW OF SURFACE WATER," Archives of Environmental Protection, vol. 40, no. 3, pp. 3-11, 2014.

[2] W. Rodhe, "Crystallization of eutrophication concepts in northern europe," 1969. [Online]. Available: https://eurekamag.com/research/026/348/026348261.php. [Accessed 64 2020].

[3] N. C. Boelee, H. Temmink, M. Janssen, C. J. N. Buisman and R. H. Wijffels, "Nitrogen and phosphorus removal from municipal wastewater effluent using microalgal biofilms," Water Research, vol. 45, no. 18, p. pp. 5925-5933, 2011.

[4] E. M. Ali, "Impact of drain water on water quality and eutrophication status of Lake Burullus, Egypt, a southern Mediterranean lagoon," African Journal of Aquatic Science, vol. 36, no. 3, pp. 267-277, 2011.

[5] D. Nagarajan, A. Kusmayadi, H.-W. Yen, C. D. Dong, D.-J. Lee, D.-J. Lee and J.-S. Chang, "Current advances in biological swine wastewater treatment using microalgaebased processes," Bioresource Technology, vol. 289, p. 121718, 2019.

[6] 2. Acién Fernández et al., "Recovery of Nutrients From Wastewaters Using Microalgae," 2018. [Online]. Available: https://frontiersin.org/articles/10.3389/fsufs.2018.00059/full. [Accessed 204 2020].

[7] J. Roostaei and Y. Zhang, "Spatially Explicit Life Cycle Assessment: Opportunities and challenges of wastewater- based algal biofuels in the United States," Algal ResearchBiomass Biofuels and Bioproducts, vol. 24, pp. 395-402, 2017.

[8] S. V. D. Hende, L. Claessens, E. D. Muylder, N. Boon and H. Vervaeren, "Microalgal bacterial flocs originating from aquaculture wastewater treatment as diet ingredient for Litopenaeus vannamei (Boone)," Aquaculture Research, vol. 47, no. 4, pp. 1075-1089, 2016.

[9] A. C. Guedes, H. M. Amaro, I. Sousa-Pinto and F. X. Malcata, "Algal spent biomass - A pool of applications," 2019. [Online]. Available: https://sciencedirect.com/science/article/pii/b978044464192 2000160. [Accessed 214 2020].

[10] "U.S. Energy Information Administration (EIA) - Source,", . [Online]. Available:

http://www.eia.gov/forecasts/aeo/electricity_generation.cfm. [Accessed 114 2020].

[11] "USEIA U.S. Energy-Related Carbon Dioxide Emissions, 2012,", . [Online]. Available:

http://www.eia.gov/environment/emissions/carbon/. [Accessed 175 2020].

[12] C. Stewart and M.-A. Hessami, "A study of methods of carbon dioxide capture and sequestration: the sustainability of a photosynthetic bioreactor approach," Energy Conversion and Management, vol. 46, no. 3, pp. 403-420, 2004.

[13] L. Lardon, A. Hélias, B. Sialve, J.-P. Steyer and O. Bernard, "Life-cycle assessment of biodiesel production from microalgae.," Environmental Science \& Technology, vol. 43, no. 17, pp. 6475-6481, 2009.

[14] R. T. Sayre, "Microalgae: The Potential for Carbon Capture," BioScience, vol. 60, no. 9, pp. 722-727, 2010.

[15] I. Barkia, N. Saari and S. R. Manning, "Microalgae for High-Value Products Towards Human Health and Nutrition," Marine Drugs, vol. 17, no. 5, p. 304, 2019.

[16] T. Suganya, M. Varman, H. H. Masjuki and S. Renganathan, "Macroalgae and microalgae as a potential source for commercial applications along with biofuels production: a biorefinery approach.," Renewable \& Sustainable Energy Reviews, vol. 55, pp. 909-941, 2016.

[17] S. M. Mobin and F. Alam, "Some Promising Microalgal Species for Commercial Applications: A review is," Energy Procedia, vol. 110, pp. 510-517, 2017.

[18] J. Benemann, J. Van Olst, M. Massingill and J. a. B. D. Weissman, "The Controlled Eutrophication Process: Using Microalgae for $\mathrm{CO} 2$ Utilization and Agricultural Fertilizer Recycling.".

[19] H. Zabed, S. Akter, J. Yun, G. Zhang, Y. Zhang and X. Qi, "Biogas from microalgae: Technologies, challenges and opportunities," Renewable \& Sustainable Energy Reviews, vol. 117, p. 109503, 2020.

[20] M. Rodero, R. Ángeles, D. Marín, I. Díaz, A. Colzi, E. Posadas, R. Lebrero and R. Muñoz, "Biogas Purification and Upgrading Technologies," 2018. [Online]. Available: https://link.springer.com/chapter/10.1007/978-3-319-773353_10. [Accessed 210 2020].

[21] C. G. Golueke, W. J. Oswald and H. B. Gotaas, "Anaerobic digestion of Algae.," Applied and Environmental Microbiology, vol. 5, no. 1, pp. 47-55, 1957.

[22] M. 2. B. 1. P. 2. Rittmann 1, Environmental Biotechnology, ed., vol. , , : McGraw Hill, 2001, p.

[23] G. F. Parkin and W. F. Owen, "Fundamentals of Anaerobic Digestion of Wastewater Sludges," Journal of 
Environmental Engineering, vol. 112, no. 5, pp. 867-920, 1986.

[24] P. Carminati, D. Gusmini, A. Pizzera, A. Catenacci, K. Parati and E. Ficara, "Biogas from mono- and co-digestion of microalgal biomass grown on piggery wastewater," Water Science and Technology, vol. 78, no. 1, pp. 103-113, 2018.

[25] F. E. Mosey and X. A. Fernandes, "PATTERNS OF HYDROGEN IN BIOGAS FROM THE ANAEROBIC DIGESTION OF MILK-SUGARS," Water Science and Technology, vol. 21, no. , pp. 187-196, 1989.

[26] D. L. Brown, "Comparison of Solid-State to Liquid Phase Anaerobic Digestion of Lignocellulosic Biomass for Biogas Production,", 2012. [Online]. Available: https://etd.ohiolink.edu/!etd.send_file?accession=osu134187 0854\&disposition=inline. [Accessed 309 2020].

[27] Passos et al., "Biogas production from microalgae grown in wastewater: Effect of microwave pretreatment," Applied Energy, vol. 108, pp. 168-175, 2013.

[28] Park et al., "Wastewater treatment high rate algal ponds for biofuel production.," Bioresource Technology, vol. 102, no. 1, pp. 35-42, 2011

[29] F. Passos, E. Uggetti, H. Carrère and I. Ferrer, "Pretreatment of microalgae to improve biogas production : A review," Bioresource Technology, vol. 172, pp. 403-412, 2014.

[30] C. Fu, T.-C. Hung, J. Y. Chen, C.-H. Su and W. T. Wu, "Hydrolysis of microalgae cell walls for production of reducing sugar and lipid extraction.," Bioresource Technology, vol. 101, no. 22, pp. 8750-8754, 2010.

[31] M. Nguyen, S. P. Choi, J. Lee, J. H. Lee and S. J. Sim, "Hydrothermal Acid Pretreatment of Chlamydomonas reinhardtii Biomass for Ethanol Production," Journal of Microbiology and Biotechnology, vol. 19, no. 2, pp. 161166, 2009.

[32] Govindjee, D. Shevela and L. O. Björn, "Evolution of the Zscheme of photosynthesis : a perspective," Photosynthesis Research, vol. 133, no. 1, pp. 5-15, 2017.

[33] Y. Chisti, "Biodiesel from microalgae beats bioethanol," Trends in Biotechnology, vol. 26, no. 3, 2008.

[34] Fontes et al., "Factors affecting the production of biomass by a nitrogen-fixing blue-green alga in outdoor culture," Biomass, vol. 13, no. 1, pp. 33-43, 1987.

[35] A. Kazbar, A. Kazbar, G. Cogne, B. Urbain, H. Marec, B. Le-Gouic, J. Tallec, H. Takache, A. Ismail and J. Pruvost, "Effect of dissolved oxygen concentration on microalgal culture in photobioreactors," Algal Research-Biomass Biofuels and Bioproducts, vol. 39, p. 101432, 2019.

[36] T. A. Costache, F. G. A. Fernández, M. M. Morales, J. Fernández-Sevilla, I. Stamatin and E. H. Molina, "Comprehensive model of microalgae photosynthesis rate as a function of culture conditions in photobioreactors," Applied Microbiology and Biotechnology, vol. 97, no. 17, pp. 7627-7637, 2013.

[37] S. Lage, Z. Gojkovic, C. Funk and F. G. Gentili, "Algal Biomass from Wastewater and Flue Gases as a Source of Bioenergy," Energies, vol. 11, no. 3, p. 664, 2018.

[38] R. Whitton, A. Mével, M. Pidou, F. Ometto, R. Villa and B. Jefferson, "Influence of microalgal $\mathrm{N}$ and $\mathrm{P}$ composition on wastewater nutrient remediation," Water Research, vol. 91, pp. 371-378, 2016.

[39] A. L. Gonçalves, J. C. Pires and M. . Simões, "A review on the use of microalgal consortia for wastewater treatment," Algal Research-Biomass Biofuels and Bioproducts, vol. 24, no. , pp. 403-415, 2017.
[40] W. J. Oswald and H. B. Gotaas, "Closure of "Photosynthesis in Sewage Treatment"," Transactions of the American Society of Civil Engineers, vol. 122, no. 1, pp. 101-105, 1957.

[41] A. Lavoie and J. Noüe, "HARVESTING MICROALGAE WITH CHITOSAN," Journal of The World Mariculture Society, vol. 14, pp. 685-694, 2009.

[42] Abdel-Raouf et al., "Microalgae and wastewater treatment.," Saudi Journal of Biological Sciences, vol. 19, no. 3, pp. 257-275, 2012.

[43] R.C. McBride and D.S. Merrick, "Innovations in Open Pond Algae Agriculture for Biofuel Production," Industrial Biotechnology, vol. 10, no. 3, pp. 162-163, 2014.

[44] P. Schulze, P. S. Schulze, L. Barreira, H. Pereira, J. A. Perales and J. Varela, "Light emitting diodes (LEDs) applied to microalgal production," Trends in Biotechnology, vol. 32, no. 8, pp. 422-430, 2014.

[45] Muñoz et al, "Algal-bacterial processes for the treatment of hazardous contaminants: A review," Water Research, vol. 40, no. 15 , pp. 2799-2815, 2006.

[46] Craggs et al., "A review of potential methods for zooplankton control in wastewater treatment High Rate Algal Ponds and algal production raceways," Algal Research-Biomass Biofuels and Bioproducts, vol. 11, pp. 211-226, 2015.

[47] V. Smith, B. Sturm, F. deNoyelles and S. A. Billings, "The ecology of algal biodiesel production," Trends in Ecology and Evolution, vol. 25, no. 5, pp. 301-309, 2010. 